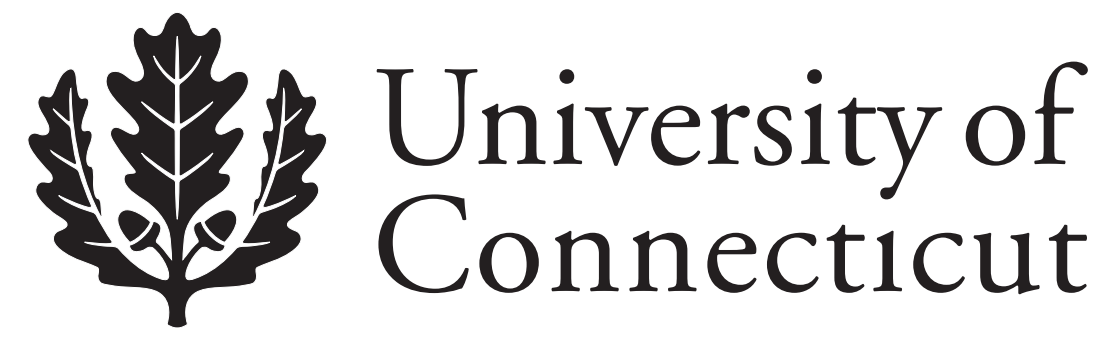

Department of Economics Working Paper Series

\title{
Business Groups and the Natural State
}

Richard N. Langlois

University of Connecticut

Working Paper 2010-29

November 2010

341 Mansfield Road, Unit 1063

Storrs, CT 06269-1063

Phone: (860) 486-3022

Fax: (860) 486-4463

http://www.econ.uconn.edu/

This working paper is indexed on RePEc, http://repec.org/ 


\begin{abstract}
Recent revisionist accounts of corporate governance in both business history and finance are challenging the tradition narrative, associated with Berle and Means (1932) and Alfred Chandler (1977), in which the American model of diffuse ownership and coherent diversification is both an inevitable outcome of economic development and perhaps a normative standard for the world to follow. This essay is an attempt to rethink that narrative in light of the continued significance of the pyramidal business group as a governance structure around the world. Drawing on the North, Wallis, and Weingast (2009) theory of the state, I argue that the evolution of corporate governance can be understood only in institutional terms and that institutional development is driven by the coalitional structure of the polity. This is true as much in open-access orders like the U. S. as in the natural states that rule most of the world. In the end, I endorse the view that the much-discussed and oft-misunderstood exceptionalism of the U. S. in corporate governance has its roots of the differential effect on the U. S. of the collapse of globalization during the middle years of the twentieth century.
\end{abstract}

Journal of Economic Literature Classification: G38, H10, K22, L22

Keywords: Business groups, corporate governance, diversification, pyramids, theory of the state. 


\section{Introduction.}

Not too many years ago, our understanding of the evolution of corporate structure in the modern era fit within a dominant theoretical narrative. We learned early on from Berle and Means (1932) that, by the early twentieth century, the owner-managed firm had given way in the United States to a corporate form in which ownership was diffuse and inactive and in which control had effectively passed to managers. Then we learned from Alfred Chandler (1977) that this managerial revolution was both inevitable and desirable. ${ }^{1}$ The separation of ownership from control allowed managers to reorganize production along efficient bureaucratic lines, creating the modern multi-unit (vertically integrated) firm (Chandler 1977) and eventually the multidivisional corporation (Chandler 1962). The progression away from owner control and toward diffuse stock holdings and professional management took place first and proceeded most quickly in the United States, whereas the vestiges of what Chandler came to call "personal” capitalism persisted in Europe, especially Britain, preventing firms in those countries from taking full advantage of economies of scale and scope, and dooming Europe (apart from Germany) to relative industrial decline (Chandler 1990).

Although this account was certainly not without its critics, it long enjoyed the status of a comfortable conventional wisdom. The situation today is arguably rather different. The conventional wisdom still remains entrenched in scholarship generally; but among specialists in business history and corporate finance, a multi-faceted revisionism is in flower. Depending on how one looks at the data, it is no longer so clear that the

\footnotetext{
1 Indeed, Lamoreaux, Raff, and Temin (2004) go so far as to accuse Chandler of Whig history
} 
separation of ownership from control was (or is) quite so rampant in the United States as the Berle and Means account would lead us to believe (Desai, Dharmapala and Fung 2005; Holderness 2009; Holderness, Kroszner and Sheehan 1999). It is also not so obvious anymore that the separation of ownership from control was more advanced, or that personal capitalism was less characteristic, in the U. S. than in Britain in the early twentieth century (Hannah 2007a, b). In place of the linear, and perhaps even triumphalist, narrative of Chandler there is now emerging a more contingent story in which forms of corporate governance vary considerably across both time and geography. Even in the United States, the vertically integrated managerial enterprise is arguably no longer the centerpiece of corporate organization (Lamoreaux, Raff and Temin 2003; Langlois 2003). And, outside the U. S. and the U. K., the dominant form of governance is not the Chandlerian firm but the pyramidal business group, a form under which, far from ceding authority entirely to professional managers, owners retain effective control over large empires (La Porta, Lopez-de-Silanes and Shleifer 1999).

These new perspectives on corporate governance in the early twenty-first century call for a reexamination, and indeed a rewriting, of the Berle-Means-Chandler narrative. In earlier work (Langlois 2003, 2007a) I have tried to rethink the issue of the latetwentieth-century vertical disintegration of the Chandlerian firm in what was essentially an American context. This essay is a preliminary attempt to widen the analysis to 
consider corporate governance more generally and to look beyond the (real or imagined)

American model of governance to alternatives that include the business group. ${ }^{2}$

\section{Institutional analysis: comparative and historical.}

The raw material for my argument will come from the New Institutional Economics in its broadest sense (Klein 2000; Langlois 1986). The economics of organization - what Williamson (1985) would call transaction-cost economics - has often been invoked to explain corporate governance. Its method calls upon what Coase in his later writings (Coase 1964) would call comparative-institutional analysis. Rather than comparing the world we observe against an abstract theoretical model (a practice Coase derided as “blackboard economics”), we should set two real-world institutions side-by-side and compare their respective costs and benefits. Implicitly in Coase, and explicitly in Williamson (1991), one explains an observed organizational form by comparing that form with hypothetical discrete alternatives in order to show that the observed form minimizes the sum of production costs and transaction costs. ${ }^{3}$

Although one can take advantage of this approach to compare specific kinds of arrangements, including those of corporate governance, the signal thought experiment in the literature is to compare "the market" as an organizational structure with "the firm" as

2 The term "business group" takes on a number of meanings in the literature, sometimes encompassing holding companies or loosely affiliated business networks (like Japanese keiretsu are supposed to be or have been). Following Colpan and Hikino (2010), however, I will consider the archetypical business group, which has three features: (1) pyramidal ownership structure; (2) unrelated diversification; and (3) family (or sometimes government) control.

3 "The underlying viewpoint that informs the comparative study of issues of economic organization is this: Transaction costs are economized by assigning transactions (which differ in their attributes) to governance structures (the adaptive capacities and associated costs of which differ) in a discriminating way" (Williamson 1985, p. 18). 
an organizational structure (Coase 1937). To an extent not often appreciated, however, the imperfect "market" in the economics of organization is actually a relatively wellfunctioning structure as real-world markets go. The underlying assumption, normally unspoken, is that relevant background institutions - things like respect for private property, contract law, courts - are all in place. Whatever transaction costs then arise are thus the result of properties inherent in "the market" itself, not of inadequacies in background institutions. ${ }^{4}$ There is generally a tacit factual or historical assumption as well: that the relevant markets exist thickly or would come into existence instantaneously if called upon. ${ }^{5}$ In the economics of organization, then, firms arise because, under certain circumstance, they are inherently superior to markets - even when those markets exist thickly and are well supported (albeit in ways normally unspecified) by background institutions.

One could actually make a similar argument about Chandler. Chandler certainly can't be accused of ignoring history: to a far greater extent than the economics of organization, he understood that markets take time to develop and that, in part at least, real-world firms often integrated vertically because markets were initially thin and

$4 \quad$ As I will argue in due course, the imperfections that the economics of organization tends to discover in "markets" are not in fact inherent but are the result of the historical state of the market (market thickness or extent) or of institutions, especially those intermediate-level institutions I will describe as market-supporting institutions.

5 Williamson (1975, p. 20) is fond of assuming that "in the beginning there were markets." He means this as a heuristic dictum not a historical claim: let's assume that markets and firms are both equally capable - that both (and other forms, too, perhaps) exist and have at their disposal the same productive capabilities. This makes it easy to conduct a (static) comparative-institutional analysis. We can compare firms and markets as discrete institutional choices and then explain observed forms strictly on the basis of differences in transaction costs (and perhaps also production costs as understood in neoclassical terms). 
underdeveloped. ${ }^{6}$ Yet, and also to a far greater extent than the economics of organization, Chandler believed in the inherent superiority of the firm - that is, of the large managerial corporation — over markets (and over other kinds of firms) at their realworld best. Steeped in Max Weber via Talcott Parsons, he saw the modern corporation much as Weber saw bureaucracy: as a modern and efficient attractor toward which developed economies were naturally tending (Langlois 2007a). And, whereas Chandler is most attentive to history, background institutions are conspicuous by their absence from his explanatory framework (if not always from his narrative). In his account, the rise of the large multi-unit enterprise in the United States was driven by impersonal economic forces: the lowering of transportation and communications costs attendant on the railroad and telegraph, along with increases in per capita income, that made it economical to produce or package goods centrally and in volume. This imperative required careful professional management to assure high throughput and thus lower costs (Chandler 1977). As the managerial firm matured, its (Weberian) advantage began to show, and the large multi-unit enterprise was able to adapt existing capabilities and develop new ones in a manner superior to older networks of owner-managed firms (Chandler 1990). Although the adoption of the managerial corporation took different

"[I]ntegration ... should be seen in terms of the enterprise's specific capabilities and needs at the time of the transaction. For example, Williamson (1985, p. 119) notes that: 'Manufacturers appear sometimes to have operated on the mistaken premise that more integration is always preferable to less.' He considers backward integration at Pabst Brewing, Singer Sewing Machine, McCormack [sic] Harvester, and Ford 'from a transaction cost point of view would appear to be mistakes.' But when those companies actually made this investment, the supply network was unable to provide the steady flow of a wide variety of new highly specialized goods essential to assure the cost advantages of scale. As their industries grew and especially as the demand for replacement parts and accessories expanded, so too did the number of suppliers who had acquired the necessary capabilities. ... The point is that an understanding of the changing boundaries of the firm required an awareness of the specific capabilities of the firm and the characteristics of the industry and market in which it operates at the time the changes were made.” (Chandler 1992, pp. 88-89.) 
paths in Europe and Japan, those differences seem more a matter of historical accident, managerial decisions, or even national culture. ${ }^{7}$ Antitrust policies, corporate law, or the state of development of financial markets seem to matter little. To put it another way, neither the economics of organization nor Chandler makes much analytical use of institutions in the wider sense treated in other regions of the New Institutional Economics (Greif 2006; Hayek 1967; North 1990).

All of this stands in sharp contrast to the literature on business groups, especially business groups outside the developed world, and to the related literature on the multinational corporation. Although much in these literatures draws upon both transaction-cost economics and the work of Alfred Chandler, the central explanatory focus lies not on a comparison of existing institutions with ideal or "optimal" ones in the abstract but rather on the roles of history and institutions in shaping organizational structure. At center stage here is an institution that most often lurks as the ignored elephant in the room of organizational economics: the state. One cannot sensibly talk about the differences in structures of corporate governance through time and around the world without talking about the evolution of the political institutions that enable and constrain choice of governance structure.

\section{The natural state.}

Indeed, I propose to invert the usual order of procedure. Rather than beginning with a world of well-developed and well-protected property rights and market-supporting institutions, let's begin by considering the precise opposite: a world with no political

Culture is of course a kind of background institution, albeit a somewhat controversial one among social theorists. On this see Jones (2006). 
institutions whatever. In such a Hobbesian state of nature, the constant threat of expropriation limits economic activity. To the extent that some economic agents succeed in producing output above subsistence, others will try to seize the proceeds. But this sorry situation creates a profit opportunity: it may pay for some agents to specialize in violence and to offer their services to productive agents in exchange for some large share of the increased output this arrangement permits (North 1981). These sedentary bandits, as Mancur Olson (1993) famously called them, seek in principle to maximize their rents by managing the productive agents effectively within their geographic reach, even to the extent of providing them with public goods; and there may even begin to emerge organizational structures of varying complexity to facilitate the rent-extraction process. Thus is born the territorial state as Max Weber understood it. ${ }^{8}$ In fact, however, the organizational complexity of a state so conceived, and of the economic society it controls, is still quite constrained. Constant threats from competing violence specialists, and the lure of territorial expansion, will lead to expenditures on offensive and defensive violence that in the limit dissipate all the rents of sedentary banditry. As North, Wallis, and Weingast (2009) have pointed out, a relatively complex division of labor cannot flourish under an array of independent sedentary bandits, what we might think of as a world of warlords. Relatively complex economic organization can emerge only to the extent that there arises among competing bandits agreement to refrain from violence, thus

8 In Weber, an entity is “a 'state' if and insofar as its administrative staff successfully upholds a claim on the monopoly of the legitimate use of violence in the enforcement of its order” (Weber 1947, p. 154). 
allowing those bandits to share the fruits of the productive economic activity their forbearance would permit.

Such an agreement, or coalition, is what North, Wallis, and Weingast call the natural state.

The natural state reduces the problem of endemic violence through the formation of a dominant coalition whose members possess special privileges. The logic of the natural state follows from how it solves the problem of violence. Elites - members of the dominant coalition - agree to respect each other's privileges, including property rights and access to resources and activities. By limiting access to these privileges to members of the dominant coalition, elites create credible incentives to cooperate rather than fight among themselves. Because elites know that violence will reduce their own rents, they have incentives not to fight. Furthermore, each elite understands that other elites face similar incentives. In this way, the political system of a natural state manipulates the economic system to produce rents that then secure political order. (North, Wallis and Weingast 2009, p. 18.)

The natural state is "natural" not in a normative sense but in the sense that it is the default mode of political organization, a form that, for the last 10,000 years or so, has dominated the vast middle ground between simple hunter-gather organization and warlordism on the one hand and the comparatively recent emergence of open-access orders on the other.

For economic activity to be beneficial to the natural state, it must generate rents without destabilizing the coalition. Thus must the state control and limit economic activity, including especially the creation of business organizations.

Among the most valuable sources of elite rents is the privilege of forming organizations that the state will support. By devising ways to support contractual organizations and then extending the privilege of forming those organizations to their members, the dominant coalition creates a way to generate and distribute rents within the coalition as well as a credible way to discipline elites because elite organizations depend on the thirdparty support of the coalition. The ability of elites to organize cooperative 
behavior under the aegis of the state enhances the elite return from society's productive resources - land, labor, capital, and organizations. (North, Wallis and Weingast 2009, p. 20.)

Placing constraints on the existence and nature of contractual organizations is one of the principal ways that the natural state distinguishes itself from an open-access order. In the latter, everyone is in principle free to create a contractual organization, which organizations can then become anonymous and perpetual: they can exist and persist independently of the individuals who create them.

One way to think about open-access orders is that rights of property and contract extend to most (in principle all) the inhabitants of the territory, not just to the members of the elite coalition. In the terms of Yoram Barzel (2001), clients have found mechanisms to limit and control their would-be protectors. Indeed, one could say that the clientinhabitants of the territory have become the "owners" of the state in the same sense that Hansmann (1996) understands the concept of ownership of contractual organizations. The clients have formal control rights, even though high transaction costs prevent them from exercising them perfectly: de facto control rights are almost always vested in legislators, executives, and bureaucracies, who effectively take on some of the character of the elite coalition of the natural state. Client-inhabitants of open-access orders are also owners in that they, not the elite coalition, are the residual claimants, although that residual claim is generally negative to the extent that (A) fewer limitations of entry generate fewer artificial rents and (B) the greater provision of public goods in such a state requires taxation of the clients. 
North, Wallis, and Weingast are rightly concerned with the question of how a natural state might make the transition to an open-access order, an issue of vital importance for economic development, since the constraints on economic activity in a natural state limit the possibilities for sustained intensive economic growth. As I have just hinted, however, there is a sense in which the line between a mature natural state and an open-access order can be somewhat indistinct. Consider the related if not fully overlapping distinction that Meir Kohn (2005) makes between predatory and associational government. The former is the Weberian (natural) state we have already met; the latter is a kind of club in which members voluntarily agree to rules and taxes in order to provide public goods. Medieval and early-modern commercial cities in Europe would be examples of the latter: they existed within the interstices, and usually with the forbearance, of territorial states, and they were effectively owned by their members. Note, however, that, as “guilds of guilds,” such cities controlled membership and limited the organizations that insiders and outsiders could form, much as in a natural state. Even though their recourse to violence was relatively limited, at least compared to territorial states, commercial cities and other merchant associations could always enforce control through ostracism and expulsion ${ }^{9}$ (Greif, Milgrom and Weingast 1994; Milgrom, North and Weingast 1990). Kohn (2005, chapter 18, manuscript p. 4) notes that predatory and associational governments tend over time to take on one another's characteristics and that modern states are a mixture of both. The same is true if we think in terms of the

In many famous instances, of course, merchant associations either contracted with mercenaries, as in the case of the condottieri system of the Italian city states (Mallett 1974), or developed their own violence capabilities, as in the case of the British East India Company (Keay 1991). In doing so, however, the merchant associations became territorial states. In the latter case, the British Empire (Ferguson 2003). 
distinction between natural states and open-access orders. Large modern open-access orders like the United States have been successful in extending ownership more fully to most of the territory's inhabitants (abolition of slavery, universal suffrage, etc.), but have at the same time become welfare states that redistribute rents among political coalitions as in a natural state, and thus have had to limited membership by (forcibly) restricting immigration. $^{10}$ And virtually all such states have a plethora of industrial and other policies that limit entry and restrict contractual organizations for reasons that arguably have to do principally with rent creation and allocation. ${ }^{11}$

In the end, then, the ideas of "state" and "organization" are interpenetrated. This is so not simply because the state shapes, limits, and controls the private organizations that engage in economic activity within its reach (North, Wallis and Weingast 2009, p. 38). The state is itself an organization; more interestingly, perhaps, commercial (and other) organizations are kinds of governments. ${ }^{12}$ An associational government like an early European commercial city - one with attenuated police powers whose clients are members rather than citizen/inhabitants - is at base more like a modern corporate

10 Rent redistribution in an open-access order takes place for the same reasons as in a natural state: to preserve the coalition. In this case, redistributing some of the gains of economic growth prevents what would otherwise be destructive class warfare (North, Wallis and Weingast 2009, pp. 124-125).

11 Contrary to what one might initially think, a (mature) natural state need not be less sophisticated as an organization than an open-access order. Precisely because of the need for elaborate economic controls, a mature natural state may employ "more government," at least along some dimensions, than an open-access order; thus movement to an open-access order, and withal to a greater level of economic development, may involve reducing the scope of government as well as reorienting its focus. Critics of so-called neo-liberalism like Ha-Joon Chang (2009) may be right that rapid liberal reforms need not always lead immediately to economic growth. But this is so only to the extent that reformers in their zeal may misunderstand and thus destabilize the rent-distributing coalitional structure of the natural state - not because the rent-creating and reallocating policies of the mercantilist state are somehow themselves conducive to development.

12 Wallis and North (2010, p. 5) define governments as “public organizations that states form,” noting that "the state in many societies is not a public organization." 
enterprise than a modern territorial city. Conversely, corporate organizations like business groups often must create some of the kinds of legal and constitutional systems we associate with territorial states, especially when the territorial patron cannot itself supply those systems. As North et al. note, "most organizations have their own internal institutional structure: the rules, norms, and shared beliefs that influence the way people behave within the organization” (North, Wallis and Weingast 2009, p. 16). For example, in pre-Meiji Japan, Mitsui and Sumitomo - favored business partners of the Shogunate were forced to create their own institutional rules.

Both families managed without money and modern economic institutions, like corporation or contract law. Consequently, both families developed house rules - constitutions dictating how business should be done; profits calculated, allocated, and disbursed; and power passed from generation to generation. House rules assigned key decisions to family councils parliaments representing clans according to precise voting formulae. Thus, in an environment without ambient business law, merchant houses formulated their own laws and, as far as we can tell, adhered to them rigidly. Private legal systems served both merchant houses well, making their behavior predictable and their promises credible. (Morck and Nakamura 2007, p. 10.)

I further maintain that the interpenetration of state and organization remains salient even at the long and indistinct boundary between sophisticated natural states and open-access orders. $^{13}$

13 Though I would stop far short of the hyperbolic conjecture of Berle and Means: "The future may see the economic organism, now typified by the corporation, not only on an equal plane with the state, but possibly even superseding it as the dominant form of social organization. The law of corporations, accordingly, might well be considered as a potential constitutional law for the new economic state, while business practice is increasingly assuming the aspect of economic statesmanship" (Berle and Means 1932, p. 313). 


\section{Business groups and economic development.}

As I suggested earlier, the economics of organization prefers thought experiments comparing idealized institutional forms like "firms" and "markets." It is among the most salient facts of economic and business history that real-world markets and institutions were not - and indeed are not - the fully formed ideal-types of these thought experiments. I have long argued (Langlois 1992; Langlois and Robertson 1995) that one cannot think about the evolution of organizational form without thinking about how the entrepreneur confronts the inadequacies of actually existing markets and the lack of what I call market-supporting institutions (Langlois 2003). For example, if necessary complementary inputs are not cheaply available on markets, the entrepreneur may be forced to produce those inputs through vertical integration even though his or her capabilities are ill adapted to the new activities ${ }^{14}$ (Silver 1984). It is my contention that this way of approaching the problem is crucial to explaining the rise of large multi-unit Chandlerian enterprise in the late nineteenth and early twentieth century (Langlois 2003; Langlois and Robertson 1995).

However novel this argument might be in the context of the economics of organization and of American business history, it is old news in the literature of business groups and the related literature of the multinational corporation (Hymer 1970; Leff 1978). Outside of the context of the United States and similar wealthy countries, the problems of poorly developed markets, and of weak, non-existent, or dysfunctional institutions, is hard to ignore. And herein lie the two principal, albeit ultimately

14 One implication is that one may have to consider a class of transaction costs in addition to those normally within the purview of the economics organization - what I call dynamic transaction costs (Langlois 1992). 
interwoven, explanations for the prevalence of business groups around the world: (A) the argument from inadequate market development or "missing markets" and (B) the argument from institutional inadequacy or dysfunction. ${ }^{15}$

Harvey Leibenstein long ago pointed out that economic growth is always a process of "gap-filling," that is, of supplying the missing links in the evolving chain of complementary inputs to production. In a developed and well functioning economy, such gap-filling can often proceed in important part through the "spontaneous" action of moreor-less anonymous markets. In other times and places, notably in less-developed economies or in sectors of developed economies undergoing systemic change, gap-filling requires other forms of organization — more internalized and centrally coordinated forms.

Gap-filling is necessary because information about some inputs are unmarketable; and because private information about markets cannot always be proven and made public information. Of course, gap-filling will also be necessary where universalistic markets have not been developed, or where the inputs are, in principle, marketable but for some reason such markets have not arisen. For any given economic activity there is a minimum quantum of various inputs that must be marshaled. If less than this minimum variety is universalistically available, the entrepreneur has the job of stepping into the breech [sic] to fill the lack of marketable inputs; i.e., he must be an input-completer. (Leibenstein 1968, p. 75).

As Leff put it, the "institution of the group is thus an intrafirm mechanism for dealing with deficiencies in the markets for primary factors, risk, and intermediate products in the developing countries”16 (Leff 1978, p 667).

15 Colpan and Hikino (2010, pp. 41-42) refer to these as the market-imperfections and political-economy explanations.

16 I should note that Leff defines business groups as excluding family-owned pyramids, but clearly his arguments apply a fortiori to groups under a broader definition. 
Earlier I used the term complementarities. It is in the context of technological complementarities that we can best understand the role of business groups in economic development. Economic historians, especially those of what we might call the Stanford School (David 1975, 1990; Rosenberg 1976), have long stressed the importance of complementarities for the pace and direction of technological change and economic growth. Even earlier, the Swedish economist Erik Dahmén $(1970,1988)$ wrote about complementarities and gap-filling in the context of what he called development blocks. ${ }^{17}$ Thus one could say that firms - and specifically business groups - exist, in part at least, in order to solve the problems of coordinating complementarities in a developing economy.

This is not to say that there aren't other methods of coordinating complementarities. The Austrian economist Rosenstein-Rodan (1943), who also saw the coordination of economic development across sectors as the key to economic growth, famously theorized about a big push in which governments would manage investment in and coordination among sectors. ${ }^{18}$ Morck (2010) argues persuasively, however, that governments have in fact had a miserable track record in attempting to orchestrate bigpush development. ${ }^{19}$ For example, Japan's big push did not take place until the government ceded ownership and control to the zaibatsu business groups (Morck and Nakamura 2007). Indeed, Britain orchestrated the development of a multitude of complementary inputs and activities during the industrial revolution without significant

17 Dahmén (1970) was first published in Swedish in 1950.

18 See also Murphy, Shleifer, and Vishny (1989).

19 This is so for reasons that a different Austrian economist, F. A. Hayek (1945), might have appreciated. 
government intervention, and even for the most part without large vertically integrated firms. In many industries it was specifically the industrial district - most famously Lancashire in textiles - that developed the necessary complementarities in an organic fashion (Robertson and Langlois 1995).

In the United States in the late nineteenth century, it was the large vertically integrated firm that brought together complementarities in many important sectors. Consider the story of refrigerated meatpacking. In the 1870s, the developing railroad network had permitted the shipment of western meat on the hoof to eastern markets, thus taking advantage of economies of scale in western pasturing. But further economies of scale were possible, notably through centralized slaughter and refrigerated shipping of dressed meat to the eastern cities. Claiming these economies required changing complementary assets and capabilities throughout the system, including the development and production of refrigerated rail cars and the establishment of a nation-wide network of properly equipped branch houses to store and merchandise the meat. It was more economical to integrate into many of these complementary stages than to face the dynamic transaction costs of persuading the various asset owners to cooperate through the market (Chandler 1977, p. 299 ff.; Porter and Livesay 1971, pp. 168-173; Fields 2003).

In Chandler's account, integration of these complementary activities into a single organization subsequently led to the internal development of related capabilities (Chandler 1990). As Edith Penrose (1959) had explained, production requires resources of various kinds, and these invariably come in lumpy bundles. Firms take advantage of 
the nonconvexities involved by integrating into new activities to which their resources are applicable, thus spreading fixed costs over more units. For example, at the turn of the twentieth century, the American meatpackers moved into production of byproducts like fertilizer, leather, soap and glue (Chandler 1990, p. 168), thus taking advantage of the resources they had built up in the processing of animals for meat. But whereas similarity can generate excess resources, complementarity can create resource bottlenecks. In order to take advantage of capabilities and resources in excess capacity, the entrepreneur must typically invest in new complementary resources (Teece 1986), and only by accident would these resources also be similar (Richardson 1972). In other words, in order to take advantage of excess resources, the entrepreneur may be required to fill gaps. In Penrose's theory, the processes of similarity and complementarity coevolve: integration into similar activities creates the need for dissimilar complementary activities; the filling of those needs in turn creates new capabilities and resources, which also come in lumpy bundles; and the process continues. For example, the American meatpackers had to invest in new distribution facilities and various kinds of new and technologically unrelated production facilities in order to take proper advantage of the byproducts of meatpacking and the capabilities they had acquired in the distribution of refrigerated foodstuffs.

Not surprisingly, the same dynamic is arguably at work in business groups, especially those in developing countries. Consider the origins of the LG Group in Korea, as related by Koo Cha-Kyung, a former company chairman.

My father and I started a cosmetic cream factory in the late 1940s. At the time, no company could supply us with plastic caps of adequate quality for cream jars, so we had to start a plastics business. Plastic caps alone were 
not sufficient to run the plastic molding plant, so we added combs, toothbrushes, and soap boxes. This plastics business also led us to manufacture electric fan blades and telephone cases, which in turn led us to manufacture electrical and electronic products and telecommunication equipment. The plastics business also took us into oil refining, which needed a tanker shipping company. The oil refining company alone was paying an insurance premium amounting to more than half the total revenue of the then largest insurance company in Korea. Thus, an insurance company was started. This natural step-by-step evolution through related businesses resulted in the Lucky-Goldstar group as we see it today. (Aguilar and Cho 1985, p. 3.)

As in Chandler's story, the "natural step-by-step evolution through related businesses” involved both spreading excess resources over similar activities and calling forth dissimilar complementary activities. But, although the activities are "related" in the broad sense that they are complementary in production, they are in the end quite unrelated in the sense of the literature on diversification. Chandler's multidivisional enterprises engage in related diversification, whereas the archetypical business group engages in unrelated diversification (Colpan and Hikino 2010, p. 26).

From the market-inadequacy perspective, the explanation is straightforward: markets in the United States, even in the late nineteenth century, were better developed in general than markets in Korea when LG got its start (and in markets in the developing world more broadly), so American entrepreneurs had a much narrower set of gaps to fill. Meat packers like Swift in the 1880s were engaged in all kinds of complementary but technologically unrelated activities like slaughtering, designing rail cars, running ice houses, and building refrigerated warehouses; but they filled these gaps in the service of a related set of products - meat, animal by-products, and later other perishable foodstuffs not at the level of an economy-wide "big push.” Moreover, as markets developed further 
over time, multi-unit enterprises could shed activities in which they had less advantage, and newer firms could rely increasingly on markets to fill what would once have been gaps $^{20}$ (Langlois 2003).

The inevitable implication of the inadequate-market explanation, of course, is convergence. Organizational structures around the world should be converging to the American-Chandlerian model, or perhaps to a post-Chandlerian alternative, as markets become more developed. We would thus expect to see a decline in the prevalence around the world of the archetypical business group: unrelated diversification should decline, and pyramidal family control should wane in favor of managerial control and dispersed stock ownership. As we have seen, however, the evidence for convergence seems weak at best, and business groups continue to thrive outside of the U.S. and the U.K (La Porta, Lopez-de-Silanes and Shleifer 1999). The problem lies not with the logic of the inadequate-market explanation but rather with the nature of the auxiliary conditions it assumes. "Markets" do not exist in the abstract, but rather in specific institutional settings. Thus an argument about convergence of forms of corporate organization and governance is ultimately an argument about the convergence of institutions - albeit a subtle and contested argument.

20 Consider a more recent example: the case of McDonald's after the fall of the Soviet Union. "When entering Russia, the company had to build a new meat plant (greenfield FDI), and create a whole ecosystem of suppliers, hitherto unavailable in a previously centrally planned economy. It did so by first undertaking in-house (internalizing) all requisite activities for the 300 or so ingredients needed by a McDonald's outlet and then gradually externalizing them to independent suppliers that it helped create. Critically it was always the intention of McDonald's to eventually outsource (as noted by global chief executive Jim Skinner in an interview with Andrew Kramer in the New York Times, February 2, 2010). As a result some suppliers went on to become large” (Pitelis and Teece 2010, p. 1261). 


\section{Business groups and the state.}

Clearly, institutions shape, restrict, and sometimes create markets. At the same time, markets shape, restrict, and sometimes create institutions. ${ }^{21}$ For the moment, however, I wish to focus on the first of these causalities: the ways in which institutions - in this case the state - affect markets.

In the missing-markets story, gaps appear to be the natural consequence of the level of economic development. At low levels of economic development, the evolution of markets has simply not yet had enough time to fill these gaps. From the institutional perspective, however, many, and often the most significant, "gaps" in developing economies are the consequence of the coalitional structure of the natural state. As we have seen, the natural state limits the right to form contractual organizations in order to forestall the destabilizing effects of competition. The resulting monopolistic privileges distort relative prices and, often more importantly, inhibit innovation (Lane 1958). Moreover, in a natural state, "valuable privileges are used to hold the political economy system together. Rather than capturing rents by charging a high price, the possessor of a privilege may exploit it by charging a low price and allocating the resource to political

21 In the end, the logic of "gap-filling" applies to institutional innovation as much as to technological or organizational innovation As I noted earlier, organizations sometimes fill gaps by taking on internally many functions we tend to associate with governments. But entrepreneurs can also seize gap-filling profit opportunities by setting up institutions external to the organization or by instigating changes in the existing institutional rules of the state (Demsetz 1967; Ruttan and Hayami 1984). Of myriad possible examples consider these two. In the nineteenth century, the Chicago Mercantile Exchange created an institution - a set of technical standards - that sorted wheat into predetermined categories in order to facilitate inspection. And in the twentieth century, MCI poured resources first into persuading the Federal Communications Commission to alter its policies and then into fomenting the breakup of AT\&T. In both cases, entrepreneurial institutional change arose to seize the profit opportunities that lay in the gaps created by technological change. In the wheat case, the change was the railroad and the grain elevator, which reduced transportation costs dramatically but caused a quality-control problem that standards and inspection could eliminate (Cronon 1991). In the telephone case, it was the advent of microwave transmission, which eliminated the natural-monopoly character of long-distance copper wires (Temin and Galambos 1987). 
allies” (North, Wallis and Weingast 2006, p. 35). The natural state is thus a breeding ground for artificial distortions and impediments that are a source - often a dominant source - of advantage for business groups. At the interfaces with economy and polity, business groups in a natural state must deal with the imperatives of the coalition of which they form a part and from which they enjoy sanction. Internally, however, groups are free to allocate resources more-or-less in accordance with the dictates of relative scarcity; to act as internal capital markets; and even to engage in some kinds of innovation. The greater the distortions and impediments imposed by the state, the greater the advantage to business groups, and the greater their power and extent.

Recall that the archetypical business group differs from the archetypical Chandlerian corporation along two (ultimately related) dimensions: diversification and control. The missing-markets story accounts for the greater unrelated diversification of business groups by the greater need in developing economies for a "big push" coordination of complementarities within the boundaries of the organization. And this is no doubt part of the story. Yet we continue to observe business groups to exist and to engage in unrelated diversification even in societies that we would consider to be highly developed open-access orders: consider the Bronfmans in Canada or the Wallenbergs in Sweden (Morck 2010).

At the level of the business unit, firms everywhere almost always engage in related diversification in the sense that their activities are coherent ${ }^{22}$ (Teece, Rumelt,

22 "A firm exhibits coherence when its lines of business are related, in the sense that there are certain technological and market characteristics common to each. A firm's coherence increases as the number of common technological and market characteristics found in each product line increases. Coherence is thus a measure of relatedness. A corporation fails to exhibit coherence when common 
Dosi and Winter 1994). That is, firms tend to accrete activities that draw on, and take advantage of excess capacity in, a set of related capabilities (Penrose 1959; Richardson 1972; Teece 1982). Such capabilities may or may not be obvious at the level of the product. For example, although the American meatpackers of the late nineteenth century did diversify into byproducts like soap and fertilizer (as the neoclassical theory of joint production would suggest), they did so because the markets on which they might have unloaded the byproducts had yet to develop. ${ }^{23}$ The core capabilities of these firms actually lay in refrigerated logistics, which they quickly exploited to distribute foodstuffs in addition to (and unrelated to the production of) meat.

Firms tend to be coherent diversifiers because of the costs of doing otherwise, which we can understand in conventional terms as diminishing returns to "management," that is, to a fixed and specific pool of knowledge. But why not decentralize management? Decentralization of management, after all, is the point of the multidivisional or M-form structure (Chandler 1962). The answer, as Oliver Williamson (1985, chapter 6) points out, is that decentralization within an organization is not costless: because of the threat of "selective intervention," lower-level managers will always behave differently, and less efficiently, when others with control rights loom above them in the hierarchy. Thus a division within a larger firm will behave differently than an identical freestanding entity.

characteristics are allocated randomly across a firm's lines of business” (Teece, Rumelt, Dosi and Winter 1994, p. 4).

23 As David Teece (1980) points out, economies of scope in the production function do not imply vertical integration, since in the absence of transaction costs firms can write contracts to allocate the returns to shared inputs. 
The issue of diversification thus returns us to the problem control. From the point of view of (let us say) a family firm standing at the apex of a diversified business group, control comes at the expense not only of the costs of selective intervention but also of the foregone benefits of the even greater portfolio diversification that would have been possible through passive investment in financial markets (Dyck and Zingales 2004). So, to the extent that we observe diversified pyramidal groups around the world, control must have benefits that offset these costs. This is especially the case when financial markets are well enough developed to offer a superior source of portfolio diversification. ${ }^{24}$

One dominant perspective is that control conveys the benefits of unproductive rent seeking. Recall that in a pyramidal structure the owner at the apex - typically a family firm - enjoys control rights over resources far in excess of its claims to residual income. This separation of control from cash-flow rights has the potential to generate large agency costs, both because it helps insulate the controllers from the market for corporate control (where one exists) and because it allows the controlling group to engage in rent-seeking behavior at the expense of minority shareholders (Bebchuk, Kraakman and Triantis 2000). This latter is called tunneling, the transfer resources among units of the group in ways that benefit those at the apex of the pyramid at the expense of minority stockholders (Johnson, La Porta, Lopez-de-Silanes and Shleifer 2000).

24 Of course, the problem of underdeveloped financial markets can sometimes be solved by tapping into well-developed markets elsewhere. Wealthy individuals in countries with poor financial institutions can and do invest in western financial markets when their governments permit (and sometimes when they don't). The multinational corporation is also a way of "importing” thicker markets and better financial institutions (Buckley and Casson 1976). For example, nineteenth- and early twentiethcentury British trading companies engaged in projects in underdeveloped regions by floating shares on the London exchanges (Jones and Wale 1998). 
On the one hand, there is certainly evidence that in many places the value of control rights exceed the value of cash-flow rights. For example, Luigi Zingales (1994) discovered that control rights on the Milan Stock Exchange can be worth as much as 82 per cent more than non-voting equity, a circumstance he ascribes to the benefits of diluting the rights of minority shareholders. And Tatiana Nenova (2003) found that the value of control-block votes is less than one per cent of company value in North America and Scandinavia but rises to more than 25 per cent in countries like France, Italy, South Korea, and Mexico. This she attributes to weaker investor protection laws and other legal strictures in those countries. At the same time, however, others have not found tunneling to be an important raison d'être for pyramiding (Khanna and Palepu 2000; Khanna and Yafeh 2007; Masulis, Pham and Zein 2010). Moreover, as Morck (2010) insists, even if tunneling does take place, potential minority investors are aware of the possibility and pay a discounted price for the stock as a result.

The other prominent explanation essentially spins the issue of tunneling in a favorable direction: internal transfers among units within a business group reflect the value of such a group as an internal capital market. Obviously an internal capital market is especially valuable when external capital markets, and markets generally, are distorted or not well developed. Amit and his coauthors find that in China family control increases value when institutional efficiency is low, even though family control in excess of ownership does not (Amit, Ding, Villalonga and Hua 2010). There is also evidence that diversified Indian business groups outperform stand-alone firms (Khanna and Palepu 2000; Siegel and Choudhury 2010). Masulis, Pham, and Zein (2010) find a similar effect across countries. 
As we teach in introductory economics courses, distorted markets impair the ability of prices to signal relative scarcities (Hayek 1945); but, especially in the context of corporate governance, missing financial markets and weak financial institutions also hamper the abilities of outsiders to monitor managers. In general, as Demsetz and Lehn (1985) argue, a noisy and unpredictable environment - product market, financial market, government policy - increases the value of internal control. At the same time, however, greater volatility increases the desirability of diversification. When financial markets and institutions are robust, this latter effect may dominate: Holderness, Kroszner, and Sheehan (1999) suggest that reduced volatility in American financial markets since the Great Depression spurred the rise of managerial stock ownership by reducing the value of diversification. $^{25}$ Notice here that, especially in the context of underdeveloped financial markets, the archetypical business group in principle has advantages at both margins control and diversification - even though Khanna and Yafeh (2005) cast doubt on the role of group diversification as a device for risk sharing. ${ }^{26}$

All of this leaves the focus squarely on the benefits of the function of control in the business group. Once again, such benefits appear clearest in the context of underdeveloped markets and of a natural state that restricts entry and distorts prices. But what explains the continued existence of diversified pyramidal groups as markets thicken, institutions mature, and states acquire the status of open-access orders? One might be inclined to throw up one's hands and wonder whether the explanation for pyramids in

But see also Desai, Dharmapala, and Fung (2005), who point to the role of tax progressivity.

26 Kuppuswamy and Villalonga (2010) find that diversified firms did better than single-segment firms during the financial crisis of 2008-2009, but they attribute this largely to more efficient internal capital allocation in the presence of external financing constraints rather than to superior risk-sharing generally. 
open-access societies might actually lie outside of the economic. Let me make two points here. (1) There may be an argument for the benefits of internal capital markets even in a world of well-developed financial markets. (2) Asserting that a country is an open-access order with well-developed financial markets should not be confused with the economist’s frequent assumption of “markets at their best.” All well-developed financial systems are not alike: as North, Wallis, and Weingast (2009) make clear, open-access orders also engage in policies of rent-transfer and entry restriction, and such policies may crucially affect the structure of corporate control in even the most advanced real-world economies.

In the Demsetz and Lehn (1985) account, the exogenous volatility of the environment increases the value of control because volatility makes it more difficult for markets to discipline managers. But there may be another sense in which "uncertainty" understood as the existence of "gaps" - increases the value of control. If it is cheaper for concentrated ownership to create or rearrange capabilities within a diversified organization than it is for those capabilities to emerge or cohere in a more decentralized setting, then an internal capital market within a business group may have an advantage in at least some kind so innovation ${ }^{27}$ (Siegel and Choudhury 2010). I don't want to push this argument too far. For one thing, there is reason to believe that a decentralized market structure is best able to engage in the kind of rapid trial-and-error learning that is most effective at the technological frontier (Nelson and Winter 1977). Moreover, business groups may be disinclined to engage in innovation that would be disruptive to their

27 Notice that this is a variant of the dynamic transaction-cost argument mentioned earlier (Langlois 1992). 
existing lines of business (Morck, Wolfenzon and Yeung 2005). Nonetheless, for innovation behind the frontier, and especially for "systemic" innovation, the ability rapidly to recombine resources and ideas internally may be $\mathrm{crucial}^{28}$ (Teece 1986). Some kinds of innovation may also require a commitment to highly specific investments, something that adequate control rights may help to safeguard (Belloc 2010).

Note that this rather inconclusive discussion was framed in the conventional mode of comparative-institutional analysis - without any specific context of background institutions. Providing such a background requires thinking about the logic of the state in the hazy boundary between mature natural state and open-access order. As we saw, open-access orders distinguish themselves from natural states in that they permit anyone - in principle - to create anonymous and perpetual contractual organization. More generally, open-access orders - again, in principle - permit free competition in both product markets and financial markets rather than restricting these markets in order to generate and transfer rents. But in real-world open-access orders, of course, the right to form contractual organizations is limited in a variety of ways, and competition is in fact restricted to varying degrees and in varying ways to generate coalitional rents.

The U. S. and the U. K. are outliers among open-access orders in both the extent of separation of ownership from control and the absence of pyramids. Looking at a comparable set of firms in various countries, La Porta, Lopez-de-Silanes and Shleifer (1999) found that, in the U. S. in 1995, 90 per cent of firms had no blockholder with more

28 I have recently argued in a case study that the vertically integrated structure of the American consumer-electronics industry of the early twentieth century (especially that of RCA, its dominant firm) actually retarded innovation in a modular technology like the radio but was beneficial in developing a systemic product like color television (Langlois 2007b). 
than a 20 percent share; in the U. K. and Canada, the figure was 60 percent. By contrast, most comparable European firms did have large blockholders; in Austria, Italy, and France, all of them did. Moreover, the pyramidal form of control is essentially nonexistent in the U. S. and the U. K. but abundant elsewhere, including Canada and Europe (Morck 2010).

From the viewpoint of the convergence account, diffuse ownership and lack of pyramidal control reflect the natural progression of financial markets, which would naturally manifest itself first in the wealthiest and most advanced economy. Strong shareholder protections and liquid capital markets reduce the benefits of control to insiders and reduce the threat of expropriation to outsiders, so we would expect concentration and pyramiding to declines as markets develop. Again, however, markets are underpinned by institutions, and it is the evolution - the convergence or lack of convergence - of institutions (or at least their functions) that ultimately needs to be explained. And that explanation requires examining the coalitional structure of states, including present-day open-access order. One can view such an endeavor as a fully contingent matter: countries encounter different exogenous conditions, which led them to adopt different sets of governance institutions. Alternatively, and perhaps more subtly, one can couch explanation in terms of "path dependency": an initial set of conditions partly determines the way in which governance institutions and governance forms coevolve (Bebchuk and Roe 1999).

Perhaps the most famous argument from path dependency places the historical origins of a country’s legal system at center stage: countries with an English common- 
law tradition are better able to adopt and enforce efficient shareholder protections than countries with a Continental civil-law tradition (La Porta, Lopez-De-Silanes, Shleifer and Vishny 1997). This hypothesis has spawned a large literature, and come under fire on the grounds that (A) civil law is in the end just as flexible as common law and (B) there are more powerful explanations of the divergences between Anglo-American institutions and Continental ones (Roe 2006).

The most powerful of these explanations point to what Deirdre McCloskey (2006, p. 11) calls the European Civil War, 1914-1989: the almost century-long interregnum between the first great globalization of the long nineteenth century (O'Rourke and Williamson 1999) and the modern globalization of the late twentieth century. The devastation of war affected the civil-law countries of Continental Europe more than it did common-law countries, creating a Public Choice environment in which stability, for both capitalists and workers, took precedence over efficient capital markets. The result was (among other things) a more-concentrated ownership structure, which was necessary to generate rents that could be reallocated politically (Roe 2003, 2006). Moreover, war, depression, Nationalism, and Communism all thrust up barriers to trade, immigration, and financial flows, which gave incumbent business interests the breathing room they needed to influence financial institutions in direction that benefited them (Rajan and Zingales 2003). It wasn't until the fall of Bretton Woods (Sylla 2006), or indeed until the fall of the Soviet Union, that renewed globalization brought about a another "great reversal" in the development of financial institutions and financial markets. In short, the European Civil War was a period in which open-access orders moved (back) in the direction of natural states. 
Thus my contention is that the explanation for the persistence of archetypical business groups in open-access orders is the same as their explanation in natural states: they arise because of those natural-state-like aspects of the polity that restrict entry and competition among organizational forms. As North, Wallis, and Weingast (2009, pp. 142-144) insist, open-access orders also require political control of economic activity and rent distribution in order to achieve stability, even though the nature of these institutions will be different from and more effective than those of the natural state. Institutions of finance and corporate governance figure prominently in such control-and-transfer schemes. Mark Roe (2003) argues that, in the social democracies of Western Europe, a bargain between corporate incumbents and labor - in which the incumbents receive protection from competition in exchange for rents and job guarantees for labor - is a way to maintain the "social peace” necessary for productive activity. In Sweden, for, example concentrated business-group control over the economy arises from a bargain with the dominant Social Democratic Party, which needed to keep capital under Swedish control in order to generate the resources necessary for its programs (Högfeldt 2005). Albeit with considerable variation and nuance, this same story holds for most other Western European countries as well as for other open-access orders like Canada and Israel. ${ }^{29}$

The puzzle here is the U. S., which, as we saw, is an outlier in terms of both blockholder concentration and pyramiding. ${ }^{30}$ “American exceptionalism,” real or

29 On Canada see Morck, Percy, Tian and Yeung (2005). And on Israel see Kosenko and Yafeh (2010), who nonetheless remain puzzled at the persistence of business groups in that country despite recent reforms in the direction of investor protection.

30 The U. K. is a slightly less pronounced outlier. Morck (2010) points to rules of the London Stock Exchange forbidding pyramids, though that begs the Public Choice question. One argument that 
imagined (Baldwin 2009), is, of course, a large and much-discussed issue. From our point of view, however, the relevant explanation might hinge on the different way in which the 1914-1989 interregnum affected the United States. The U. S. was never a battleground. And, although tariffs and regulations flourished during the Depression era, the U. S. constituted by itself a large internal market that substituted in part for strong international competition. Crucially, perhaps, the U.S. never suffered the same great inflations as Europe after World War I, which led the American median voter, who held more equity than her European counterpart, to favor at the margin regulation protecting investors more than those guaranteeing wages and employment (Perotti and Von Thadden 2006), an effect bolstered by the majoritarian (rather than parliamentary) voting system in the U. S. (Pagano and Volpin 2005).

It nonetheless remains puzzling that there are essentially no pyramids whatever in the U. S. Although on average American firms more closely resemble the publicly traded widely held firm of Berle and Means than do firms most other places, the U. S. still displays significant ownership concentration and many instances of unrelated (conglomerate) diversification. But no pyramids. Morck argues that the elimination of pyramids was explicitly part of the American political response to the Great Depression (Morck 2010), and he identifies the double taxation of corporate dividends as the primary weapon (Morck and Yeung 2005). But American laws intended to protect minority later privatized - rather than family pyramids to control competition and capital flows. 
shareholders themselves also strew innumerable impediments to transferring resources among divisions that aren’t wholly owned. ${ }^{31}$

Some might be inclined to say that government policy that affirmatively discourages pyramidal ownership (as well as to some extent concentration and unrelated diversification) is evidence that the U. S. has moved further in the direction of an openaccess order than have other developed polities. Perhaps. But, as I have emphasized, American policies are as much the result of a Public Choice landscape as are (say) European policies, or indeed those of Brazil, China, Russia, or Korea. It is not obvious that we have available a natural experiment in which level of ownership concentration, degree of unrelated diversification, or extent of pyramidal control are determined purely by the natural development of "market forces," even though it is clear that such forces have an effect on the Public Choice environment from which the institutional constraints of the state emerge.

31 For example, the Swiss firm Roche, which had owned 60 per cent of the American firm Genentech, discovered that American law effectively prevented them from consolidating resources between the two companies, which were increasingly competing in the same markets. As a result, Roche was forced to buy out Genentech’s minority shareholders (Baldwin, Becker and Dessain 2010). 


\section{References.}

Aguilar, F. J. and D. S. Cho. 1985. "Gold Star Co. Ltd," Case No. 9-385264, Harvard Business School.

Amit, Raphael H., Yuan Ding, Belen Villalonga and Zhang Hua. 2010. "The Role of Institutional Development in the Prevalence and Value of Family Firms," Harvard Business School Finance Working Paper No. 1507823.

Baldwin, Carliss Y., Bo Becker and Vincent Dessain. 2010. "Roche’s Acquisition of Genentech," Case No. 9-210-040, Harvard Business School.

Baldwin, Peter. 2009. The Narcissism of Minor Differences: How America and Europe Are Alike - an Essay in Numbers. New York: Oxford University Press.

Barzel, Yoram. 2001. A Theory of the State: Economic Rights, Legal Rights, and the Scope of the State. New York: Cambridge University Press.

Bebchuk, Lucian A., Reinier Kraakman and George Triantis. 2000. "Stock Pyramids, Cross-Ownership, and Dual Class Equity: The Mechanisms and Agency Costs of Separating Control from Cash-Flow Rights," in Randall K. Morck, ed., Concentrated Corporate Ownership. Chicago: University of Chicago Press, pp. 295-318.

Bebchuk, Lucian Arye and Mark J. Roe. 1999. "A Theory of Path Dependence in Corporate Ownership and Governance," Stanford Law Review 52(1): 127-170.

Belloc, Filippo. 2010. "The Dark Side of Shareholder Protection: CrossCountry Evidence from Innovation Performance," Department of Economics Working Paper Series 583, University of Siena. 
Berle, Adolph A. and Gardiner C. Means. 1932. The Modern Corporation and Private Property. New York: Macmillan.

Buckley, Peter J. and Mark Casson. 1976. The Future of the Multinational Enterprise. New York: Holmes \& Meier Publishers.

Chandler, Alfred D., Jr. 1962. Strategy and Structure: Chapters in the History of the Industrial Enterprise. Cambridge: MIT Press.

Chandler, Alfred D., Jr. 1977. The Visible Hand: The Managerial Revolution in American Business. Cambridge: The Belknap Press.

Chandler, Alfred D., Jr. 1990. Scale and Scope: The Dynamics of Industrial Capitalism. Cambridge: The Belknap Press.

Chandler, Alfred D., Jr. 1992. "Organizational Capabilities and the Economic History of the Industrial Enterprise," The Journal of Economic Perspectives 6(3): 79-100 (Summer).

Coase, Ronald H. 1937. "The Nature of the Firm," Economica (N.S.) 4: 386405.

Coase, Ronald H. 1964. "The Regulated Industries -- Discussion," The American Economic Review 54(3): 194-197.

Colpan, Asli M. and Takashi Hikino. 2010. "Foundations of Business Groups: Toward an Integrated Framework," in Asli M. Colpan, Takashi Hikino and James R. Lincoln, eds., Oxford Handbook of Business Groups. Oxford: Oxford University Press, pp. 15-66. 
Cosgel, Metin and Thomas J. Miceli. 2009. "State and Religion," Journal of Comparative Economics 37(3): 402-416.

Cronon, William. 1991. Nature's Metropolis: Chicago and the Great West. New York: W. W. Norton.

Dahmén, Erik. 1970. Entrepreneurial Activity and the Development of Swedish Industry, 1919-1939. Homewood, IL: Richard D. Irwin.

Dahmén, Erik. 1988. "'Development Blocks' in Industrial Economics," Scandinavian Economic History Review 36(1): 3-14.

David, Paul A. 1975. Technical Choice Innovation and Economic Growth: Essays on American and British Experience in the Nineteenth Century. New York: Cambridge University Press.

David, Paul A. 1990. "The Dynamo and the Computer: An Historical Perspective on the Modern Productivity Paradox," The American Economic Review 80(2): 355-361.

Demsetz, Harold. 1967. "Toward a Theory of Property Rights," The American Economic Review 57(2): 347-359.

Demsetz, Harold and Kenneth Lehn. 1985. "The Structure of Corporate Ownership: Causes and Consequences," The Journal of Political Economy 93(6): 1155-1177.

Desai, Mihir A., Dhammika Dharmapala and Winnie Fung. 2005. "Taxation and the Evolution of Aggregate Corporate Ownership Concentration," National Bureau of Economic Research Working Paper 11469. 
Dyck, Alexander and Luigi Zingales. 2004. "Private Benefits of Control: An International Comparison," The Journal of Finance 59(2): 537-600.

Ferguson, Niall. 2003. Empire: The Rise and Demise of the British World Order and the Lessons for Global Power. New York: Basic Books.

Greif, Avner. 2006. Institutions and the Path to the Modern Economy: Lessons from Medieval Trade. New York: Cambridge University Press.

Greif, Avner, Paul Milgrom and Barry R. Weingast. 1994. "Coordination, Commitment, and Enforcement: The Case of the Merchant Guild," Journal of Political Economy 102(4): 745-776.

Hannah, Leslie. 2007a. "The 'Divorce' of Ownership from Control from 1900 Onwards: Re-Calibrating Imagined Global Trends," Business History 49(4): 404 - 438.

Hannah, Leslie. 2007b. "Pioneering Modern Corporate Governance: A View from London in 1900," Enterprise and Society 8(3): 642-686 (September).

Hansmann, Henry. 1996. The Ownership of Enterprise. Cambridge: The Belknap Press.

Hayek, F. A. 1945. "The Use of Knowledge in Society," The American Economic Review 35(4): 519-530.

Hayek, F. A. 1967. Studies in Philosophy, Politics and Economics. Chicago: University of Chicago Press. 
Högfeldt, Peter. 2005. "The History and Politics of Corporate Ownership in Sweden," in Randall K. Morck, ed., A History of Corporate Governance around the World: Family Business Groups to Professional Managers. Chicago: University of Chicago Press.

Holderness, Clifford G. 2009. "The Myth of Diffuse Ownership in the United States," Review of Financial Studies 22(4): 1377-1408 (April).

Holderness, Clifford G., Randall S. Kroszner and Dennis P. Sheehan. 1999. "Were the Good Old Days That Good? Changes in Managerial Stock Ownership since the Great Depression," The Journal of Finance 54(2): 435-469.

Hymer, Stephen. 1970. "The Efficiency (Contradictions) of Multinational Corporations," The American Economic Review 60(2): 441-448.

Johnson, Simon R., Rafael La Porta, Florencio Lopez-de-Silanes and Andrei Shleifer. 2000. "Tunneling," American Economic Review 90(2): 22-27.

Jones, Eric L. 2006. Cultures Merging: A Historical and Economic Critique of Culture. Princeton: Princeton University Press.

Jones, Geoffrey and Judith Wale. 1998. "Merchants as Business Groups: British Trading Companies in Asia before 1945," The Business History Review 72(3): 367-408.

Keay, John. 1991. The Honourable Company: A History of the English East India Company. New York: Macmillan.

Khanna, Tarun and Krishna Palepu. 2000. "Is Group Affiliation Profitable in Emerging Markets? An Analysis of Diversified Indian Business Groups," The Journal of Finance 55(2): 867-891. 
Khanna, Tarun and Yishay Yafeh. 2005. "Business Groups and Risk Sharing around the World," Journal of Business 78(1): 301-340.

Khanna, Tarun and Yishay Yafeh. 2007. "Business Groups in Emerging Markets: Paragons or Parasites?," Journal of Economic Literature 45(2): 331-372 (June).

Klein, Peter G. 2000. "New Institutional Economics," in Boudewijn Bouckeart and Gerrit De Geest, eds., Encyclopedia of Law and Economics. Cheltenham: Edward Elgar, pp. 456-89.

Kohn, Meir. 2005. The Origins of Western Economic Success: Commerce, Finance, and Government in Pre-Industrial Europe. Hanover: Dartmouth College, Unpublished Manuscript. Available at: http://www.dartmouth.edu/ mkohn/.

Kosenko, Konstantin and Yishay Yafeh. 2010. "Business Groups in Israel," in Asli M. Colpan, Takashi Hikino and James R. Lincoln, eds., Oxford Handbook of Business Groups. Oxford: Oxford University Press.

Kuppuswamy, Venkat and Belen Villalonga. 2010. "Does Diversification Create Value in the Presence of External Financing Constraints? Evidence from the 20082009 Financial Crisis," Harvard Business School Finance Working Paper 1569546.

La Porta, Rafael, Florencio Lopez-de-Silanes and Andrei Shleifer. 1999. "Corporate Ownership around the World," The Journal of Finance 54(2): 471-517 (April).

La Porta, Rafael, Florencio Lopez-De-Silanes, Andrei Shleifer and Robert W. Vishny. 1997. "Legal Determinants of External Finance," The Journal of Finance 52(3): 1131-1150. 
Lamoreaux, Naomi R., Daniel M. G. Raff and Peter Temin. 2003. "Beyond Markets and Hierarchies: Toward a New Synthesis of American Business History," American Historical Review 108(2): 404-433 (April).

Lamoreaux, Naomi R., Daniel M. G. Raff and Peter Temin. 2004. "Against Whig History," Enterprise and Society 5(3): 376-387 (September).

Lane, Frederic C. 1958. "Economic Consequences of Organized Violence," The Journal of Economic History 18(4): 401-417.

Langlois, Richard N. 1986. Economics as a Process: Essays in the New Institutional Economics. New York: Cambridge University Press.

Langlois, Richard N. 1992. "Transaction Cost Economics in Real Time," Industrial and Corporate Change 1(1): 99-127.

Langlois, Richard N. 2003. "The Vanishing Hand: The Changing Dynamics of Industrial Capitalism," Industrial and Corporate Change 12(2): 351-385 (April).

Langlois, Richard N. 2007a. The Dynamics of Industrial Capitalism: Schumpeter, Chandler, and the New Economy. London: Routledge.

Langlois, Richard N. 2007b. "Organizing the Electronic Century," Department of Economics Working Paper Series 2007-07, University of Connecticut.

Langlois, Richard N. and Paul L. Robertson. 1995. Firms, Markets, and Economic Change: A Dynamic Theory of Business Institutions. London: Routledge. 
Leff, Nathaniel H. 1978. "Industrial Organization and Entrepreneurship in the Developing Countries: The Economic Groups," Economic Development and Cultural Change 26(4): 661-675.

Leibenstein, Harvey. 1968. "Entrepreneurship and Development," The American Economic Review 58(2): 72-83.

Mallett, Michael Edward. 1974. Mercenaries and Their Masters: Warfare in Renaissance Italy. Totowa, NJ: Rowman and Littlefield.

Masulis, Ronald W., Peter K. Pham and Jason Zein. 2010. "Family Business Groups around the World: Financing Advantages, Control Motivations and Organizational Choices." SSRN eLibrary. http://ssrn.com/paper=1363878.

McCloskey, Deirdre N. 2006. The Bourgeois Virtues : Ethics for an Age of Commerce. Chicago: University of Chicago Press.

Milgrom, Paul, Douglass C. North and Barry R. Weingast. 1990. "The Role of Institutions in the Revival of Trade: The Law Merchant, Private Judges, and the Champagne Fairs," Economics and Politics 2: 1-23 (March).

Morck, Randall. 2010. "The Riddle of the Great Pyramids," in Asli M. Colpan, Takashi Hikino and James R. Lincoln, eds., Oxford Handbook of Business Groups. Oxford: Oxford University Press.

Morck, Randall K., Michael Percy, Gloria Tian and Bernard Yeung. 2005. "The Rise and Fall of the Widely Held Firm: A History of Corporate Ownership in Canada," in Randall K. Morck, ed., A History of Corporate Governance around the World: Family Business Groups to Professional Managers. Chicago: University of Chicago Press, pp. 65-148. 
Morck, Randall and Masao Nakamura. 2007. "Business Groups and the Big Push: Meiji Japan's Mass Privatization and Subsequent Growth," National Bureau of Economic Research Working Paper Series No. 13171.

Morck, Randall, Daniel Wolfenzon and Bernard Yeung. 2005. "Corporate Governance, Economic Entrenchment, and Growth," Journal of Economic Literature 43(3): 655-720.

Morck, Randall and Bernard Yeung. 2005. "Dividend Taxation and Corporate Governance," The Journal of Economic Perspectives 19(3): 163-180.

Murphy, Kevin M., Andrei Shleifer and Robert W. Vishny. 1989. "Industrialization and the Big Push," The Journal of Political Economy 97(5): 1003-1026.

Nelson, Richard R. and Sidney G. Winter. 1977. "In Search of Useful Theory of Innovation," Research Policy 5: 36-76.

Nenova, Tatiana. 2003. "The Value of Corporate Voting Rights and Control: A Cross-Country Analysis," Journal of Financial Economics 68(3): 325-351.

North, Douglass C. 1981. Structure and Change in Economic History. New York: Norton.

North, Douglass C. 1990. Institutions, Institutional Change and Economic Performance. New York: Cambridge University Press.

North, Douglass C., John Joseph Wallis and Barry R. Weingast. 2006. "A Conceptual Framework for Interpreting Recorded Human History," 
NBER working paper series 12795, National Bureau of Economic Research.

North, Douglass C., John Joseph Wallis and Barry R. Weingast. 2009. Violence and Social Orders: A Conceptual Framework for Interpreting Recorded Human History. New York: Cambridge University Press.

O’Rourke, Kevin and Jeffrey G. Williamson. 1999. Globalization and History: The Evolution of a Nineteenth-Century Atlantic Economy. Cambridge: MIT Press.

Olson, Mancur. 1993. "Dictatorship, Democracy, and Development," The American Political Science Review 87(3): 567-576.

Pagano, Marco and Paolo F. Volpin. 2005. "The Political Economy of Corporate Governance," The American Economic Review 95(4): 1005-1030.

Penrose, Edith T. 1959. The Theory of the Growth of the Firm. Oxford: Basil Blackwell.

Perotti, Enrico C. and Ernst-Ludwig Von Thadden. 2006. "The Political Economy of Corporate Control and Labor Rents," Journal of Political Economy 114(1): 145-174 (February).

Pitelis, Christos N. and David J. Teece. 2010. "Cross-Border Market CoCreation, Dynamic Capabilities and the Entrepreneurial Theory of the Multinational Enterprise," Industrial and Corporate Change 19(4): 1247-1270 (August). 
Rajan, Raghuram G. and Luigi Zingales. 2003. "The Great Reversals: The Politics of Financial Development in the Twentieth Century," Journal of Financial Economics 69: 5-50.

Richardson, G. B. 1972. "The Organisation of Industry," The Economic Journal 82(327): 883-896.

Robertson, Paul L. and Richard N. Langlois. 1995. "Innovation, Networks, and Vertical Integration," Research Policy 24(4): 543-562 (July).

Roe, Mark J. 2003. Political Determinants of Corporate Governance: Political Context, Corporate Impact. Oxford: Oxford University Press.

Roe, Mark J. 2006. "Legal Origins, Politics, and Modern Stock Markets," Harvard Law Review 120(2): 460-527.

Rosenberg, Nathan. 1976. Perspectives on Technology. New York: Cambridge University Press.

Rosenstein-Rodan, Paul N. 1943. "Problems of Industrialisation of Eastern and South-Eastern Europe," The Economic Journal 53(210/211): 202211.

Ruttan, Vernon W. and Yujiro Hayami. 1984. "Toward a Theory of Induced Institutional Change," The Journal of Development Studies 20(4): 203-223.

Siegel, Jordan I. and Prithwiraj Choudhury. 2010. "A Reexamination of Tunneling and Business Groups: New Data and New Methods," Harvard Business School Strategy Unit Working Paper No. 10-072. 
Silver, Morris. 1984. Enterprise and the Scope of the Firm. London: Martin Robertson.

Sylla, Richard. 2006. "Schumpeter Redux: A Review of Raghuram G. Rajan and Luigi Zingales's "Saving Capitalism from the Capitalists"," Journal of Economic Literature 44(2): 391-404.

Teece, David J. 1980. "Economies of Scope and the Scope of the Enterprise," Journal of Economic Behavior \& Organization 1(3): 223247 (September ).

Teece, David J. 1982. "Towards an Economic Theory of the Multiproduct Firm," Journal of Economic Behavior \& Organization 3(1): 39-63 (March ).

Teece, David J. 1986. "Profiting from Technological Innovation: Implications for Integration, Collaboration, Licensing, and Public Policy," Research Policy 15(6): 285-305.

Teece, David J., Richard Rumelt, Giovanni Dosi and Sidney Winter. 1994. "Understanding Corporate Coherence: Theory and Evidence," Journal of Economic Behavior and Organization 23(1): 1-30 (January).

Temin, Peter and Louis Galambos. 1987. The Fall of the Bell System: A Study of Prices and Politics. New York: Cambridge University Press.

Wallis, John Joseph and Douglass C. North. 2010. "Defining the State," Mercatus Center Working Paper 10-26, George Mason University.

Weber, Max. 1947. The Theory of Social and Economic Organization. New York: Oxford University Press. 
Williamson, Oliver E. 1985. The Economic Institutions of Capitalism. New York: The Free Press.

Williamson, Oliver E. 1991. "Comparative Economic Organization: The Analysis of Discrete Structural Alternatives," Administrative Science Quarterly 36(2): 269-296.

Zingales, Luigi. 1994. "The Value of the Voting Right: A Study of the Milan Stock Exchange Experience," The Review of Financial Studies 7(1): 125-148. 